\title{
Evaluation of MODIS Spectral Indices for Monitoring Hydrological Dynamics of a Small, Seasonally-Flooded Wetland in Southern Spain
}

\author{
Linlin $\mathrm{Li}^{1}$ • Anton Vrieling ${ }^{1}$ • Andrew Skidmore ${ }^{1} \cdot$ Tiejun Wang $^{1}$. \\ Antonio-Román Muñoz ${ }^{2,3}$ • Eren Turak ${ }^{4}$
}

Received: 6 February 2015 / Accepted: 14 July 2015 / Published online: 8 August 2015

(C) The Author(s) 2015. This article is published with open access at Springerlink.com

\begin{abstract}
Monitoring spatio-temporal dynamics of hydrology in seasonally-flooded wetlands is important for water management and biodiversity conservation. Spectral data and derived indices from the Moderate Resolution Imaging Spectroradiometer (MODIS) have been used for hydrological monitoring of large wetlands. However, comparable studies for small wetlands $\left(<25 \mathrm{~km}^{2}\right)$ are lacking. Our aims are to examine whether MODIS-derived indices at 500-m spatial resolution can perform this task for small wetlands, and to compare the performance of various indices. First we evaluated if water levels are a good indicator for wetland inundation extent. A high correlation between water level and Landsatderived inundation extent was found $\left(R^{2}=0.957\right)$. Secondly, we compared 10 years of water level fluctuations with seven spectral indices at a 16-day interval. The Tasseled Cap brightness index (TCBI) had the highest correlation with water level for the complete time series including dry and wet years. Thirdly, we analyzed how these indices behave for areas with different inundation characteristics. Again TCBI showed a consistently accurate performance, which was independent of inundation frequency. We therefore conclude that TCBI is
\end{abstract}

Linlin $\mathrm{Li}$

1.1i-1@utwente.nl

1 Department of Natural Resources, Faculty of Geo-information Science and Earth Observation (ITC), University of Twente, P.O. Box 217, 7500 AE Enschede, The Netherlands

2 Laboratory of Biogeography, Diversity and Conservation, Department of Animal Biology, Faculty of Sciences, University of Malaga, E-29071 Malaga, Spain

3 Department of Didactic of Science, Faculty of Science Education, University of Malaga, E-29071 Malaga, Spain

4 Office of Environment and Heritage, Sydney, NSW, Australia the best-suited index for monitoring of hydrological variability in small seasonally-flooded wetlands such as the Fuente de Piedra lake in southern Spain. We recommend testing this index further for other seasonally-flooded wetlands in semiarid areas.

Keywords Remote sensing · Hydrology · Time series · Wetland inundation $\cdot$ Mediterranean

\section{Introduction}

Seasonally or intermittently flooded wetlands are ecologically important ecosystems in arid, semi-arid, and Mediterraneantype regions (Roshier et al. 2001; Waterkeyn et al. 2008; Haas et al. 2009). Forty-five percent of the Ramsar-listed seasonally-flooded inland wetlands are found in these climate zones. They undergo periodic cycles of inundation and drought, primarily in response to variability in precipitation and evapotranspiration (Ruiz 2008). In arid, semi-arid and Mediterranean environments, about $30 \%$ of Ramsar-listed seasonal wetlands are small-sized, measuring between 10 and 2500 ha. Despite their small size, they often act as critical refuge and breeding areas, offer food sources for wildlife, and harbor many plant and animal species that would otherwise not survive in the surrounding landscape (Gibbs 1993; Semlitsch and Bodie 1998; Roshier et al. 2002; Zacharias et al. 2007; Sim et al. 2013). There is concern that seasonal wetlands are often neglected due to their ephemeral character and small size. The abundance and quality of seasonal wetlands around the world is declining rapidly due to global climate change, expansion of agricultural land and irrigation schemes (Roshier et al. 2001; Castañeda and Herrero 2008; Zacharias and Zamparas 2010). Although the European Union (Habitats Directive 1992) and the Ramsar Convention 
(Ramsar Convention on Wetlands 2002) include seasonal wetlands in their conservation plans, only a subset of them are considered. The lack of knowledge about the changes in wetland extent of these aquatic systems makes conservation a difficult task for resource managers. Hence, an urgent need exists at national and international levels to report and monitor changes in wetland extent and conditions for large areas, using cost-effective tools, and including the important small-sized wetlands.

Hydrological dynamic processes, mainly expressed by spatial and temporal variation in inundation status, are important determinants of the formation and maintenance of a seasonally flooded wetland. Hydrological modifications may strongly affect ecosystem functioning and normally result in shifting species distributions and composition (Koning 2005; Robledano et al. 2010), especially for species that are sensitive to hydroperiod variability (Roshier et al. 2002; Baldwin et al. 2006). It may also affect other ecosystem functions including ground water recharge and nutrient cycling (Leibowitz 2003). Therefore, it is important to monitor the wetland inundation dynamics for water management, ecosystem assessment and biodiversity conservation.

In situ water level gauges are a main data source for understanding hydrological dynamics and essential for quantifying temporal patterns of water fluctuation with good temporal resolution (Alsdorf et al. 2007). Gauge stations are typically located on large rivers, lakes and canals, but less frequently in seasonally flooded areas. Due to the inaccessibility of certain regions or financial and operational constraints, globally many wetlands lack gauge stations resulting in a limited knowledge and understanding of their hydrological conditions (Alsdorf et al. 2003). While gauge measurements provide key data on the wetland hydrology, they may offer little information about spatial patterns of hydrologically-relevant variables like inundation status (Alsdorf et al. 2007; Huang et al. 2014).

Remote sensing provides temporally and spatially continuous synoptic observation of ecosystem processes, and these observations may allow for monitoring of spatio-temporal hydrological variability for large areas in a repeatable and cost effective manner (Smith 1997). Two types of remote sensing instruments are suitable for monitoring wetland hydrology at local and regional scales, i.e. microwave and optical sensors. The microwave technique of synthetic aperture radar (SAR) can provide imagery under all weather conditions and thus has been used for monitoring spatial and temporal patterns of flood inundation (e.g. Richards et al. 1987; Townsend 2001; Bourgeau-Chavez et al. 2005; Wdowinski et al. 2008; MartiCardona et al. 2010; Kim et al. 2014). A main disadvantage of $\mathrm{SAR}$ is that the resulting backscattered signal is a complex combination of effects that depend on incidence angle, vegetation density and orientation, relative water height and wind effects. This could cause opposite backscatter responses for similar conditions, and the effective disentangling of such effects requires additional information (Smith 1997; O'Grady and Leblanc 2014). Radar (or laser) altimeters can monitor water heights in reservoirs and lakes with a higher temporal resolution, but may miss many water bodies due to the spacing between the satellite orbits (Alsdorf et al. 2007). Optical remote sensors, such as those onboard Landsat and SPOT, have been used frequently for small wetlands monitoring. For example, Herrero and Castaneda (2009) used a series of 52 Landsat images to monitor the flooding surface of small saline wetlands in northeast Spain over the past 20 years. While providing accurate spatial information about flood extent, these sensors do not yet allow frequent and continuous monitoring over large regions that suffer from persistent cloud cover. In comparison, the relatively coarse spatial resolution $(>100 \mathrm{~m})$ imagery derived from satellite sensors such as AVHRR (Advanced Very High Resolution Radiometer) and MODIS (Moderate Resolution Imaging Spectroradiometer) provides more consistent and frequent observations over long time-spans, making such imagery potentially well-suited for spatio-temporal analysis of wetland hydrology.

An often-used approach to study temporal changes from coarse-resolution optical sensors is to summarize their spectral information in multispectral indices and consequently study the spatio-temporal variation of these indices. The best-known multi-spectral index is the Normalized Difference Vegetation Index (NDVI) (Tucker 1979) that combines spectral reflectance measurements from red and near-infrared (NIR) bands. The NDVI provides a measure of the photosynthetic activity of the green vegetation and NDVI time series have been used extensively for monitoring vegetation dynamics (Pettorelli et al. 2005; Beck et al. 2006; Vrieling et al. 2011, 2013; Petus et al. 2013). It has also been used for water/land delineation (Chipman and Lillesand 2007; Borro et al. 2014) as water strongly absorbs light in the NIR spectral region (causing low reflectance) while much less absorption occurs over land surfaces. Other indices have been specifically developed for detecting and monitoring surface wetness (e.g. Gao 1996; McFeeters 1996; Xiao et al. 2002a; Xu 2006). These mostly combine shortwave infrared (SWIR) or near infrared (NIR) bands, i.e. the spectral domain containing specific physical water absorption features, and visible (VIS) spectral regions. In general, NIR-SWIR indices are mainly proposed for vegetation water content detection while VIS-NIR (SWIR) combinations are almost all proposed for the detection of open water.

Several studies have explored coarse spatial resolution data for monitoring flood duration, timing and frequency of ephemeral wetlands (Xiao et al. 2005; Guerschman et al. 2011; Feng et al. 2012; Chen et al. 2013; Huang et al. 2014; Tornos et al. 2015). Most of these studies used MODIS data to monitor flood extent by differentiating inundated/noninundated or mixed pixels. Until present, there have been few attempts to link water level changes to temporal patterns 
of spectral indices. One exception is Ordoyne and Friedl (2008) who demonstrated the utility of multi-temporal MODIS data for characterizing the hydrologic regime of the Everglades in South Florida, USA. However, all MODIS studies focused on relative large wetlands covering at least $50 \mathrm{~km}^{2}$. Whether MODIS and its derived spectral indices are suitable to describe and monitor variations in water level for small $\left(<25 \mathrm{~km}^{2}\right)$ seasonal wetlands has not yet been tested.

This paper aims to explore the potential of MODIS-derived spectral indices for characterizing the temporal variability in the hydrology of small shallow wetlands. Specifically, the objectives are (1) to investigate if water level is a good proxy of wetland hydrological variability by establishing a relationship between water level variation and inundated area for a small ( $\left.\sim 14 \mathrm{~km}^{2}\right)$ wetland in southern Spain; (2) to evaluate if time series of MODIS-derived spectral indices can effectively capture the hydrological variability of this wetland in relation to the water-level data; and (3) to explain how varying inundation characteristics within the wetland affect the temporal behavior of these indices.

\section{Study Area}

The study was carried out in Fuente de Piedra lake $\left(36^{\circ} 06^{\prime} \mathrm{N}\right.$, $4^{\circ} 45^{\prime} \mathrm{W}$ ), a shallow and saline (athalassohaline) lake and associated marshland with an area of 1364 ha. It occupies the center of a topographically endorheic basin with a catchment area of about $150 \mathrm{~km}^{2}$ in southern Spain, situated between the Guadalquivir watershed and the Guadalhorce watershed (Heredia et al. 2010) (see Fig. 1). The study site is one of the most important breeding sites for the Greater Flamingo (Phoenicopterus roseus) in the Mediterranean region, second only to the Camargue, France (Geraci et al. 2012). Its natural values were recognized and listed as a Wetland of International Importance (Ramsar) and Special Protection Area for Birds (SPA). It is designated by the environmental council of the Andalusian regional government as a Nature Reserve, and therefore it is a protected site.

The wetland is fed by five small rivers, rainfall, and highly mineralized ground water (Kohfahl et al. 2008). Evaporation from the lake surface constitutes the main water output. It has a maximum depth of approximately $70 \mathrm{~cm}$ during the 10 -year study period and experiences both seasonal and interannual variations of water level and inundation extent that are predominantly linked to variability in precipitation and evaporation. The mean annual rainfall is $460 \mathrm{~mm}$ and mean annual evaporation is approximately $1600 \mathrm{~mm}$. Usually the lake is flooded in autumn (September-October), has its highest water levels during spring (February-March), and dries up partially or completely around June and July (García and Niell 1993; Kohfahl et al. 2008). During these summer months the excess evaporation causes salt to deposit on the soil (see Fig. 1c).
Different vegetation communities are found within and outside the wetland system. Dense vegetation containing reeds, saltmarshes and tamarisks (see Fig. 1e) are present in channels feeding into the lake, and form a natural purification buffer of runoff water entering the lake. On small elevated dikes and islets inside the lake, drought- and saline-tolerant vegetation (e.g. Sarcocornia, Suaeda and Arthrocnemun) is present (Ministry of Agriculture, Fisheries and Enviroment 2013) (see Fig. 1d). In drier years with low water levels, surface water does not reach this vegetation, but during wet years it may be partially inundated (Wang 2008). Planktonic and submerged macrophytes are generally negligible except for extremely wet years such as 1990 and 1998 (García et al. 1997; Conde-Álvarez et al. 2012). During the period considered in this study (2000-2009) when annual precipitation levels were low, no significant development of aquatic vegetation was observed, which can partly be attributed to the efforts to purify the wastewater from nearby towns (Ministry of Agriculture, Fisheries and Environment 2013). Surrounding the wetland area, olive trees and wheat are cultivated. While this is predominantly rainfed agriculture, groundwater extraction from wells is sometimes used as supplementary irrigation.

\section{Data}

\section{Water Level Data}

The Fuente de Piedra lake water level data have been collected since 1983 using a limnograph. This mechanical recorder draws the curve of water level fluctuations on a paper by registering the movements of a flute floating in a well which connects with the lakebed. The daily mean values of the water level are subsequently calculated and stored in a database. The instrument measures the water surface height from the bottom of the lake (i.e. the 0 -cm water level indicates that the lake is dry, even though values below 0 representing groundwater levels are recorded as the well is deeper than the lake). In this study, a 10-year daily mean water level dataset between 2000 and 2009 was obtained from Consejería de Medio Ambiente, Natural Reserve of Fuente de Piedra (Junta de Andalucía).

\section{Remote Sensing Imagery and Pre-Processing}

We used 78 Landsat TM/ETM+ images of Path/Row 201/34, acquired through the Global Visualization Viewer (GLOVIS; http://glovis.usgs.gov/) of the United States Geological Survey. The TM sensor has a spatial resolution of $30 \mathrm{~m}$ for the six reflective bands and $120 \mathrm{~m}$ for the thermal band. Landsat ETM + images consist of eight spectral bands with a spatial resolution of $30 \mathrm{~m}$ for bands 1 to 5 and band 7 . Resolution for band 6 (thermal infrared) is $60 \mathrm{~m}$ and resolution for band 8 (panchromatic) is $15 \mathrm{~m}$. In our study, 

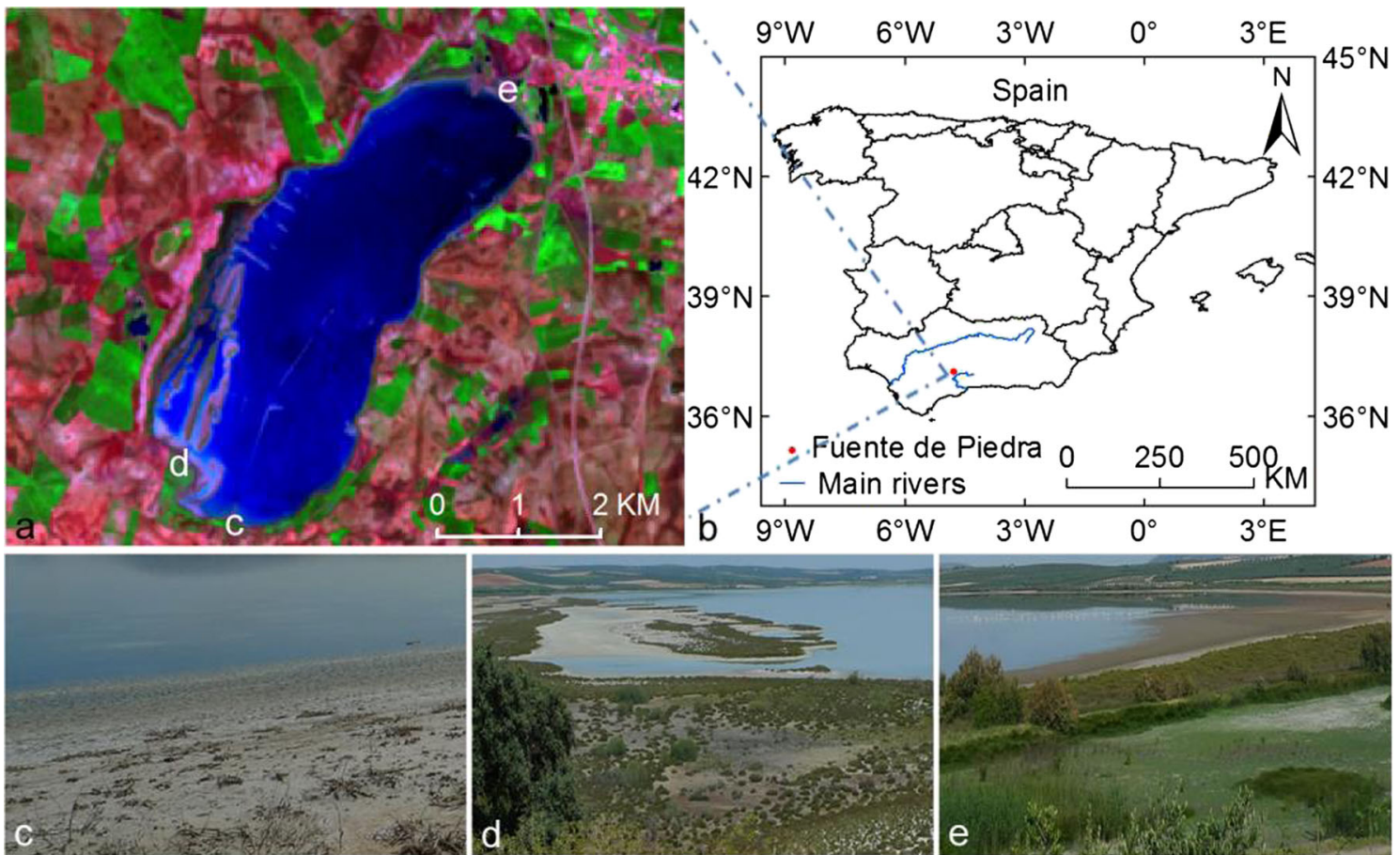

Fig. 1 Location of the study area. a Color composite image displaying bands 7, 4, 2 as RGB (Landsat 7 ETM+ on May 2, 2000); b map of Spain showing the location of Fuente de Piedra; c, d and e photos (June 2014) showing exposed soil, salt-resistant vegetation and marshland surrounding the lake. The approximate location of the photos is shown in

transformed the raw digital numbers (DN) contained in the images to top of atmosphere (TOA) reflectance according to the Landsat 7 Science Data Users Handbook (Irish 2000).

The MODIS sensor has 36 spectral bands of which seven are specifically designed for studying the land surface, i.e.: blue (459-479 nm), green $(545-565 \mathrm{~nm})$, red $(620-670 \mathrm{~nm})$, near infrared (841-876 nm), and shortwave infrared (SWIR ${ }_{1}$ : 1230-1250 nm, SWIR 2 : 1628-1652 nm, SWIR 3 : 2105$2155 \mathrm{~nm}$ ). The MODIS Land Science Team provides a suite of standard MODIS data products to the users, including the Nadir BRDF-Adjusted Reflectance (NBAR) 16-day
Table 1 Number of Landsat images available per year $(2000$ 2009) and month that are cloudfree over the study area, and consequently used in this study

\begin{tabular}{lllllllllll}
\hline & 2000 & 2001 & 2002 & 2003 & 2004 & 2005 & 2006 & 2007 & 2008 & 2009 \\
\hline January & & 1 & 1 & & 1 & 1 & 1 & & & \\
February & 1 & & 1 & & & & & & & \\
March & & & 1 & & & & & 1 & 1 & 1 \\
April & & & 1 & 1 & 1 & 1 & & & 1 & 1 \\
May & 2 & & 1 & 1 & 1 & & & 1 & & 1 \\
June & 1 & 1 & 2 & & 1 & 1 & 2 & 2 & 1 & 1 \\
July & 1 & & 1 & 2 & & 1 & & & 1 & 2 \\
August & 1 & 1 & & 2 & & & & 1 & 1 & 2 \\
September & & 1 & 1 & & 1 & 1 & & 1 & & 1 \\
October & & & & 1 & 1 & & & & 1 & 1 \\
November & & 1 & & 1 & & 2 & 2 & 1 & 1 & 1 \\
December & 1 & & & & 2 & 1 & 1 & 1 & 1 & \\
Total & 7 & 5 & 9 & 8 & 8 & 8 & 6 & 8 & 8 & 11 \\
\hline
\end{tabular}


composite product (MCD43A4). This product provides 500$\mathrm{m}$ resolution reflectance data for each of the MODIS bands (1-7) adjusted using a bidirectional reflectance distribution function (BRDF) to model the values as if they were taken from nadir view (Schaaf et al. 2002). The product thus removes view angle effects, and in addition masks cloud cover and reduces atmospheric contamination. For this study MCD43A4 composites were used to evaluate if coarseresolution index time series can capture the hydrological variability of the Fuente de Piedra lake. We used all 16-day composites between 2000 and 2009, resulting in 227 images.

\section{Methods}

\section{Evaluating Water Level as a Proxy for Inundated Area}

To evaluate if water level gauge measurements provide a good proxy for inundated area and thus allow to effectively describe the wetland's hydrological conditions, we used the Landsat scenes to set a high-resolution baseline. To discriminate water from non-water we used the Normalized Difference Water Index (NDWI) developed by McFeeters (1996). It has been widely used as an index for surface water detection (Bai et al. 2011; Rokni et al. 2014). We acknowledge that NDWI may not be the most effective for inundation detection in case of dominant floating vegetation or submerged vegetation (Rodriguez et al. 2014), but this was not the case for the wetland considered here (Study Area section). The NDWI ranges from -1 to 1 , with values above 0 generally representing water bodies. However the threshold values applied to separate water from land may vary significantly from one scene to the next due to aerosol interference and variable solar/viewing geometry (Ji et al. 2009; Feng et al. 2012). Therefore we established threshold values for each individual NDWI image using the Otsu thresholding algorithm. The algorithm assumes that the image contains two classes of pixels following a bi-modal histogram (foreground pixels and background pixels). It then calculates the optimum threshold separating the two classes that minimizes the weighted withinclass variance (Otsu 1979).

The inundated area derived from each of the 78 Landsat scenes was linked to the corresponding water levels. We fitted a second-order polynomial regression through the data to describe the inundation status in relation to water level variation. When the recorded water level is $0 \mathrm{~cm}$, the lake is dry, i.e. the inundated area is $0 \mathrm{~km}^{2}$. Therefore, the regression analysis is only performed for those dates when the recorded water level was above $0 \mathrm{~cm}$.

In addition, we calculated the per-pixel water occurrence frequency (WOF) by evaluating for each pixel the ratio between the number of images for which the pixel was inundated and the total number of images (i.e., 78). Based on this, we classified the wetland areas into five classes: never inundated $(\mathrm{WOF}=0)$, seldom inundated $(0<\mathrm{WOF} \leq 0.15)$, occasionally inundated $(0.15<\mathrm{WOF} \leq 0.3)$, sometimes inundated $(0.3<$ $\mathrm{WOF} \leq 0.45)$ and often inundated $(0.45<\mathrm{WOF} \leq 0.6)$.

\section{MODIS-Derived Spectral Indices}

A range of spectral indices have been proposed to perform surface wetness detection from multi-spectral imagery in different contexts. These all follow the same logic as the NDVI (Tucker 1979), i.e. a difference between two spectral bands divided by the sum of the two. McFeeters (1996) introduced the Normalized Difference Water Index (NDWI) to delineate open water features using the green and near-infrared (NIR) band. Xu (2006) found that NDWI often does not distinguish between water areas and built-up land, and proposed the Modified Normalized Difference Water Index (MNDWI) by substituting the SWIR band for the NIR band. Several spectral indices combining the NIR and SWIR bands have been proposed using different portions of the SWIR region (Ji et al. 2011). These include the Normalized Difference Water Index (NDWI, Gao 1996) (referred as $\mathrm{LSWI}_{\mathrm{B} 5}$ in this paper) and the Land Surface Water Index (LSWI, Xiao et al. 2002b) (referred as $\mathrm{LSWI}_{\mathrm{B} 6}$ in this paper) which use the SWIR-band centered at 1.24 and $1.64 \mu \mathrm{m}$, respectively. The combined NIR/SWIR indices are sensitive to leaf water and soil moisture and for this reason widely adopted for studying vegetation phenology, vegetation change and seasonal inundation (Xiao et al. 2005, 2006; Ordoyne and Friedl 2008; Yan et al. 2010; Campos et al. 2012; Davranche et al. 2013). Table 2 summarizes the five most common band-ratio indices adopted for water detection (including open water, vegetation water content, and soil moisture).

Except for spectral band-ratio indices using two multispectral bands, there are also approaches synthesizing information contained in multiple bands. The tasseled cap transformation, first suggested by Kauth and Thomas (1976) for Landsat MSS, is a useful tool for compressing spectral data into a few bands that can be directly associated with the physical parameters of the land surface (Crist and Cicone 1984; Crist 1985). The first three components of the Tasseled Cap transformation are brightness, greenness and wetness. Brightness, hereinafter referred to as "Tasseled Cap Brightness Index (TCBI)", is a weighted sum of all six bands and correlated to texture and moisture content of soils (Crist et al. 1986). Greenness is a contrast between near-infrared and visible reflectance, and is thus a measure of the presence and density of green vegetation. Wetness, hereinafter referred to as "Tasseled Cap Wetness Index (TCWI)", contrasts the sum of the visible/ near infrared with the shortwave infrared bands, providing a measure of soil moisture tension (Crist et al. 1986; Jian et al. 2012) and plant moisture (Cohen 1991; Jin and Sader 2005; Toomey and Vierling 2005). The coefficients of TCBI and 
Table 2 List of spectral indices tested in this study

\begin{tabular}{|c|c|c|c|c|c|}
\hline Spectral index & Original purpose & Equation & $\begin{array}{l}\text { MODIS } \\
\text { bands }\end{array}$ & $\begin{array}{l}\text { Code in this } \\
\text { manuscript }\end{array}$ & Reference \\
\hline Normalized difference water index & Open water detection & $\mathrm{NDWI}=\frac{\rho_{\text {Green }}-\rho_{\text {NIR }}}{\rho_{\text {Green }}+\rho_{\text {NIR }}}$ & B4, B2 & & McFeeters (1996) \\
\hline $\begin{array}{l}\text { Modified normalized difference } \\
\text { water index }\end{array}$ & Open water detection & MNDWI $=\frac{\rho_{\text {Green }}-\rho_{\text {SWIR }}}{\rho_{\text {Green }}+\rho_{\text {SWIR }}}$ & B4, B6 & & $\mathrm{Xu}(2006)$ \\
\hline Normalized difference water index & Vegetation liquid water & $\mathrm{NDWI}=\frac{\rho_{\text {NIR }}-\rho_{S W I R}}{\rho_{N I R}+\rho_{S W I R}}$ & B2, B5 & $\mathrm{LSWI}_{\mathrm{B} 5}$ & Gao (1996) \\
\hline Land surface water index & Rice flooding mapping & $\mathrm{LSWI}=\frac{\rho_{\text {NIR }}-\rho_{\text {SWIR }}}{\rho_{\text {NIR }}+\rho_{\text {SWIR }}}$ & B2, B6 & $\mathrm{LSWI}_{\mathrm{B} 6}$ & Xiao et al. (2002b) \\
\hline $\begin{array}{l}\text { Normalized difference vegetation } \\
\text { index }\end{array}$ & $\begin{array}{l}\text { Vegetation monitoring; } \\
\text { water mapping }\end{array}$ & $\mathrm{NDVI}=\frac{\rho_{N I R}-\rho_{\mathrm{Re} d}}{\rho_{N I R}+\rho_{\mathrm{Re} d}}$ & B2, B1 & & $\begin{array}{l}\text { Tucker (1979); Chipman } \\
\text { and Lillesand (2007) }\end{array}$ \\
\hline
\end{tabular}

TCWI proposed by Zhang et al. (2002) were used for MODIS data (Table 3).

For each 16-day MCD43A4 composite, we calculated all the spectral indices that are designed to be correlated to surface wetness. Because the resulting MODIS-derived time-series of $\mathrm{LSWI}_{\mathrm{B} 5}$ and $\mathrm{LSWI}_{\mathrm{B} 6}$ showed a strong similarity, we only present $\mathrm{LSWI}_{\mathrm{B} 6}$ results in this paper.

\section{Evaluation of MODIS-Derived Spectral Indices for Monitoring Hydrological Variability}

For each 16-day time step and spectral index we calculated the mean value of the MODIS pixels contained within the lake. Only pixels whose centers were inside the lake boundary were included. The temporal patterns of average MODIS indices for the entire lake were then analyzed. This resulted in a single average 10-year time series from 2000 to 2009 for the lake for each spectral index with a 16-day temporal resolution.

To analyze which index most accurately describes the temporal hydrological variability, we averaged the water level data to 16-day periods corresponding to the MODIS composite period. Pearson's correlation coefficients were calculated between each water index series and the corresponding water level data.

Besides the lake-average indices, we also performed correlation analysis between water level and index time series for single MODIS pixels. For this analysis we included pixels within $1 \mathrm{~km}$ outside the lake as the surrounding vegetation may also reflect the hydrology condition in the lake. In an attempt to group areas of similar behavior, we converted the Landsat-derived inundation frequency map to vector layers. From these layers we calculated the spatial mean index values of the MODIS pixels contained within each inundation occurrence zone and within the $1 \mathrm{~km}$ buffer area, and then related these to water level data. In addition, we calculated the dynamic range for each index time series (defined here as the absolute difference between the 5 th and 95th percentile of all index values) to examine which spectral index responds most strongly to the hydrological fluctuations. To better understand how the behavior of each spectral index within an inundation zone relates to the spectral properties, we also calculated the spatial mean reflectance for each MODIS band and each inundation class for several different water levels ranging from -30 to $62 \mathrm{~cm}$.

\section{Results and Discussion}

\section{Relationship Between Water Level and Inundated Area}

Figures 2 and 3 illustrate the changes in inundated area as a function of water level. The data are most accurately fitted with a second order polynomial that indicates a strong positive relationship $\left(R^{2}=0.957\right)$ between water level and inundated area. Similar high correlations using a second order polynomial were also achieved by Sippel et al. (1998) and Jung et al. (2011), but other mathematical relationships are also found between the two parameters, including a linear function (Liu et al. 1983), a power function (Hayashi and van der Kamp 2000), and an exponential function (Mahe et al. 2011, 2013). The type of relationship is largely dependent on the lake bathymetry (Alsdorf et al. 2007; Medina et al. 2010) or river morphology (Smith 1997). Other effects also play a role. For example wind effects (Wang 2008) may explain the range of inundated area

Table 3 Tasseled Cap coefficients for MODIS NBAR (source: (Zhang et al. 2002))

\begin{tabular}{lllllrrr}
\hline Index & Band 1 & Band 2 & Band 3 & Band 4 & Band 5 & Band 6 & Band 7 \\
\hline Tasseled Cap Brightness Index (TCBI) & 0.3956 & 0.4718 & 0.3354 & 0.3834 & 0.3946 & 0.3434 \\
Tasseled Cap Wetness Index (TCWI) & 0.10839 & 0.0912 & 0.5065 & 0.4040 & -0.2410 & -0.4658 & -0.5306 \\
\hline
\end{tabular}


Fig. 2 Inundation maps derived from multi-temporal Landsat imagery corresponding to different water levels and corresponding date

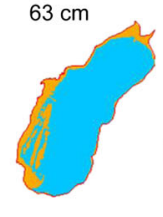

27-04-2004

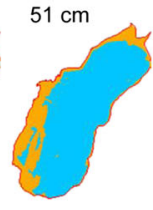

22-01-2004

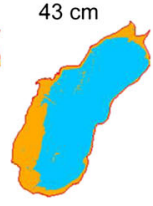

22-04-2002

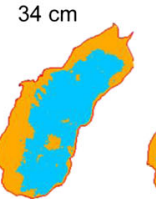

30-06-2004

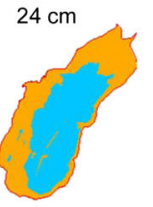

$12-12-2000$

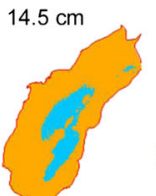

$10-12-2005$

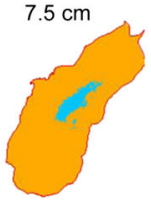

08-11-2005

Open water

between 4.0 and $6.5 \mathrm{~km}^{2}$ around the water level of $22 \mathrm{~cm}$ (Fig. 3). Despite the scattering around the regression line, Fig. 3 shows a strong relationship between water level and inundation area. Consequently water level data can be used in this study as a proxy for the important hydrological fluctuations occurring in the wetland.

Figure 4 presents the inundation frequency map obtained from the number of times each pixel was inundated in the 78 Landsat images. Central regions (shown in blue) experience variable water depths during the wet season. Never inundated regions (shown in white) occur in the southwest and north. The southwest areas are known as "Canchones del Suroeste", which are unique natural islets in the lake providing good nesting areas for flamingos only in years with very high water levels when foxes and other predators cannot reach these islets (RendónMartos 1996). These areas are mudflats and partly covered by drought- and salt-resistant vegetation (e.g. Sarcocornia, Suaeda and Arthrocnemun) (Fig. 1d). The northern fringe of the lake is covered by dense vegetation which is a combination of marsh vegetation mixed with reeds, rushes and tamarisks (Fig. 1e).

\section{MODIS-Derived Indices vs. Water Level}

Figure 5 presents a visual comparison of the multi-temporal profiles of six spectral indices throughout a 10 year period (2000-2009) in conjunction with water level. During the 10 years of study, the water level of the lake has varied substantially, both within and between years. All hydrological cycles have a filling phase of strong water level increase during September to November. Water levels remain relatively

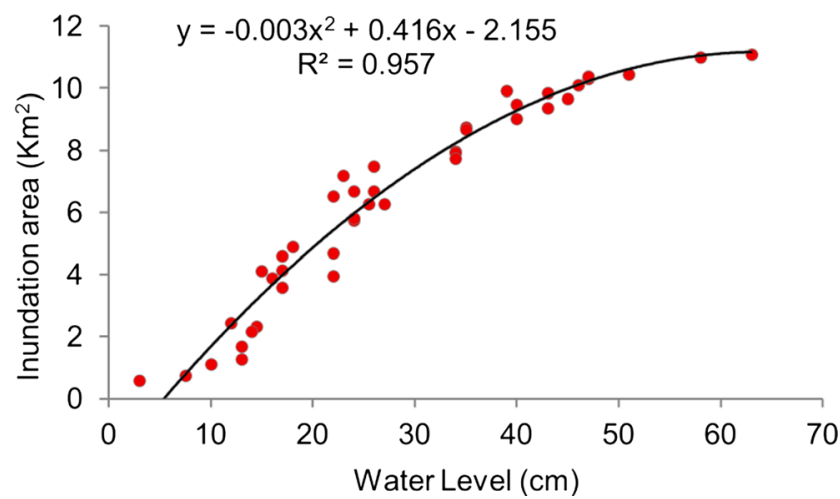

Fig. 3 Relationship between measured water level and Landsat-derived inundation areas. A second order polynomial was fitted to the data high until spring (February-March). This is followed by a drying period with dropping water levels, resulting in a complete dry up of the lake around June-July. Based on the interannual variations in lake water levels, two categories of hydrological years can be identified: relatively wet years $(2000$ to 2004 and 2009) and relatively dry years (2005 to 2008). During wet years, the lake water levels start rising from late September to mid-October. Throughout the wet years, water depths are higher than the multi-annual average and water persists on the surface for longer periods (Mid-October to late June). Dry years are characterized by longer dry seasons which can start as early as May and end in October.

Visual inspection of the temporal graph (Fig. 5) indicates a relatively stronger correspondence between water level and MNDWI, TCBI and TCWI. All the indices except TCBI were positively related to the water level data. The TCBI values exhibited a smooth, regular seasonal annual pattern with a higher variability in index values. The TCWI and MNDWI curves also showed clear seasonal patterns but with more noise. During the 10-year study period, the TCWI and MNDWI values were mostly below 0 , with a smaller dynamic range of TCWI than that of MNDWI. The other indices showed a more random pattern. One exception is that $\mathrm{LSWI}_{\mathrm{B} 6}$ closely follows the water level fluctuation during dry years (2005-2008).

Table 4 shows the Pearson's correlation coefficients between each water index and the corresponding water level data. There was a strong negative correlation between TCBI

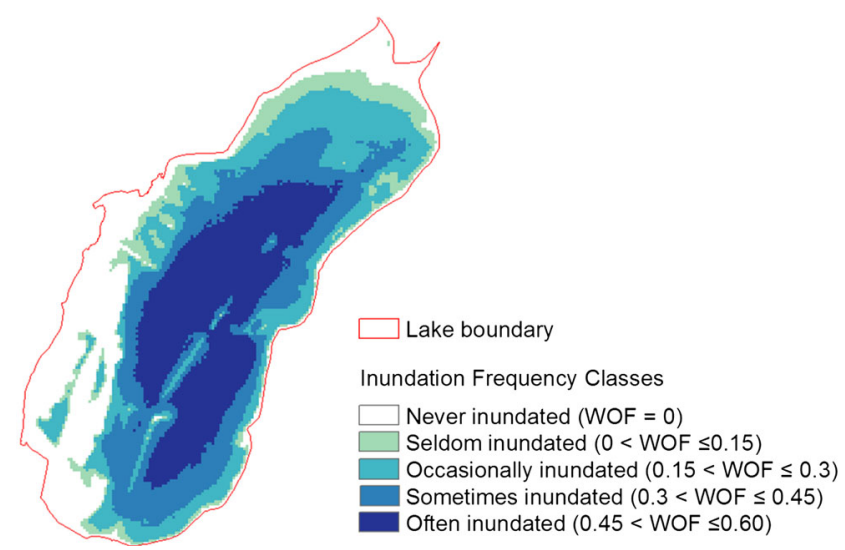

Fig. 4 Inundation frequency classes map obtained from the number of Landsat images between 2000 and 2009 that showed inundation. WOF stands for water occurrence frequency 

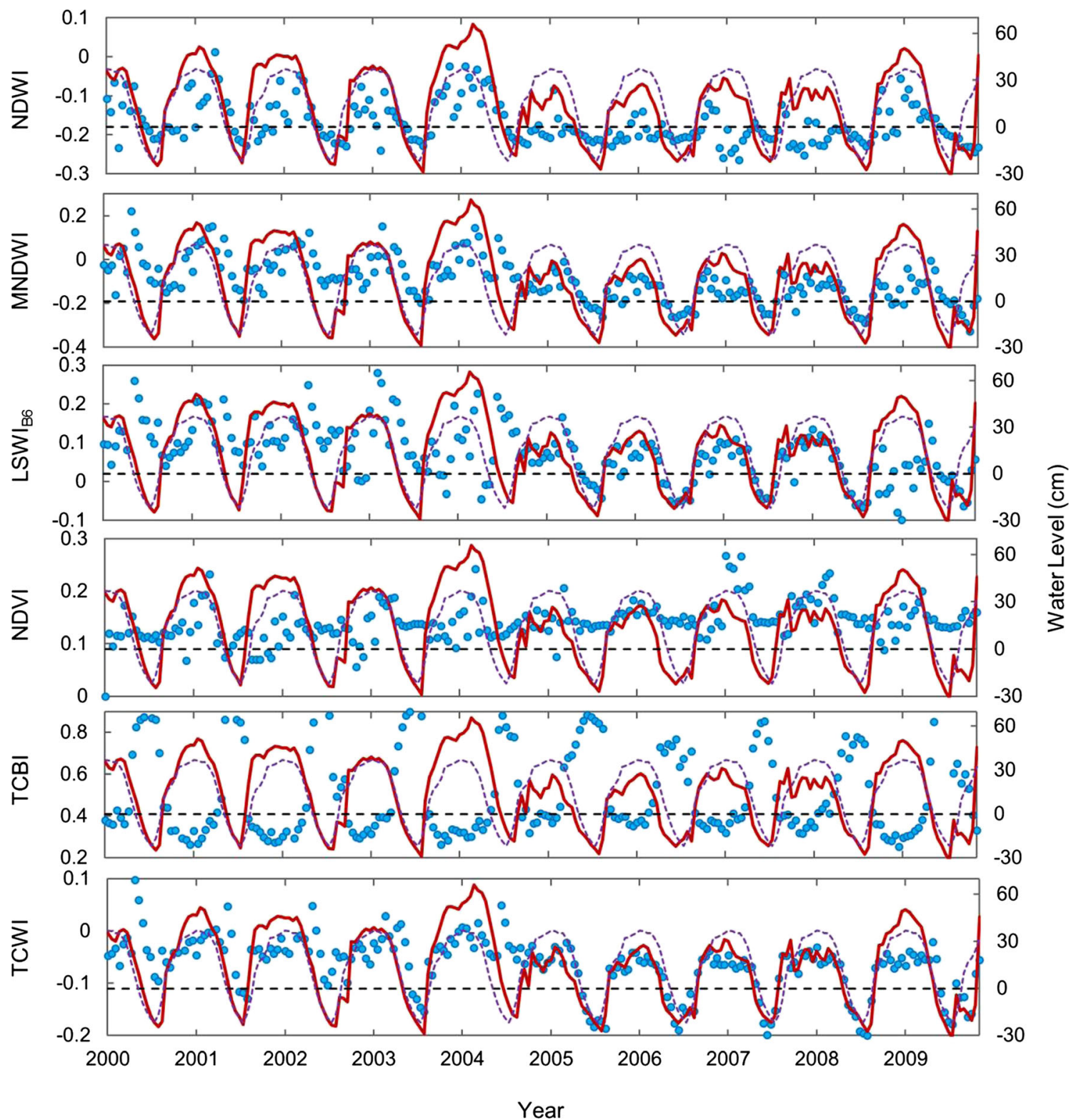

Fig. 5 Comparison between spectral index time series from MODIS and water level data. The solid red line represents in-situ water level measurements; the blue points represent spatial mean MODIS index values of the Fuente de Piedra lake for each MODIS composite; the

purple dashed line represents the multi-annual average water level fluctuation; the black dashed line indicates the $0 \mathrm{~cm}$ water depth (no open water in the lake)

and water level time series, which is consistent with the findings by Ordoyne and Friedl (2008) for the Florida Everglades. TCBI is a linear combination of all spectral bands with positive coefficients (Table 3); the higher the overall reflection of the ground surface across the spectrum, the higher the TCBI. Because water is a strong absorber of radiation across the visible and infrared portion of the spectrum, a decrease of water in the system (including open water and soil moisture), will cause an increase in TCBI. When water retreats completely from the ground surface (i.e. no open water), measured water level variation is associated with the relative water content in the soil. A high water content makes soils darker (hence low TCBI) than if these were dry, particularly for soils with low organic matter content (Jensen 2009). Strong correlations were consistent between TCBI and water level for both dry and wet years, suggesting that TCBI is a reliable index for hydrological monitoring in the Fuente de Piedra lake under a wide range of conditions.

In contrast to TCBI, TCWI had the highest positive correlation coefficient with water level $(r=0.67)$ for the 10-year period, with a much higher correlation coefficient $(r=0.92)$ for the dry years (2005-2008). This result confirms findings by other studies (Ordoyne and Friedl 2008; Van Trung et al. 2013) and can be explained by the fact that water strongly 
Table 4 Pearson's correlation coefficients between in-situ water level data and MODIS-derived indices for the whole time series (2000-2009), for the wet years only (2000-2004 and 2009), and for the dry years only (2005-2008)

\begin{tabular}{lccc}
\hline & $2000-2009$ & $2005-2008$ & $2000-2004$ and 2009 \\
\hline NDWI & 0.58 & 0.29 & 0.66 \\
MNDWI & 0.52 & 0.74 & 0.39 \\
LSWI $_{B 6}$ & 0.28 & 0.75 & 0.22 \\
NDVI & 0.12 & 0.35 & 0.15 \\
TCBI & -0.87 & -0.92 & -0.88 \\
TCWI & 0.67 & 0.92 & 0.53 \\
\hline
\end{tabular}

absorbs radiation in the SWIR part of the electro-magnetic spectrum (Campbell 2002). The correlation coefficient for wet years (2000-2004 and 2009) was much lower $(r=0.53)$ and can be attributed to higher TCWI values in the dry season (May-July) of these wet years as compared to dry years, even if the water level is the same. These high values may be explained by salt deposition on the soil surface during the dry season, which occurs particularly in wet years when more water evaporates. The presence of salt causes the TCWI to increase considerably due to the high spectral reflectance of crusted saline soil surfaces in the visible and near-infrared regions of the spectrum (Howari et al. 2002; Koshal 2012). The different findings for the dry and wet years suggest that TCWI can be a proper index for monitoring wetland hydrological variability in non-saline wetlands, but not for saline wetlands with seasonal salt deposits.

While TCBI and TCWI clearly exhibited the highest correlation with water level fluctuations, we found that band-ratio indices also gave reasonable correlation coefficients, but this was largely season-dependent. For dry years, $\mathrm{LSWI}_{\mathrm{B} 6}$ and MNDWI had a stronger relation with water level than NDVI and NDWI. This could be partly attributed to the smaller sensitivity of NIR reflection to variations in soil moisture, vegetation water content (Eitel et al. 2006; Olsen et al. 2013) and open water (Campbell 2002; Li et al. 2003) as compared to SWIR reflection. Low correlation between $\mathrm{LSWI}_{\mathrm{B} 6} / \mathrm{MNDWI}$ and water level for wet years may again be explained by the accumulation of salt at the soil surface (as for TCWI). NDWI showed a higher correlation coefficient with water level for wet years, which is likely to due to the higher variation in open water extent for which NDWI is designed. For all years, the NDVIwater level correlation coefficients were very low $(r<0.4)$.

\section{Temporal Behaviour of MODIS-Derived Indices in Response to Inundation Characteristics}

Figure 6 shows the correlation coefficient between MODISderived indices and water level for individual MODIS pixels. Important spatial variations can be observed. Generally, for
NDWI, $\mathrm{LSWI}_{\mathrm{B} 6}$ and NDVI the sign of the correlation coefficient was opposite when comparing areas inside and outside the lake, while for TCBI, TCWI and MNDWI, the sign was the same.

Comparison of Pearson's correlation coefficients for different inundation frequency zones indicated that the sign and strength of correlations between water level and the MODIS-derived indices were highly dependent on inundation frequency (Table 5). TCBI was an exception as it showed high correlations with water level in all six inundation frequency classes. This result demonstrated that TCBI was sensitive to hydrological variability as expressed by fluctuations in both open water extent and soil moisture. Because the TCBI is a linear combination of all MODIS bands with positive coefficients (Table 3 ), TCBI's sensitivity to hydrological variability across classes should be explained by an overall increase of reflectance with decreasing water levels. In fact, Fig. 7 shows that this is the case for all inundation classes. This suggests that TCBI is well suited for monitoring relative wetness under a wide range of hydrological conditions.

TCWI was positively related to water level in all inundation classes. The highest correlation $(r=0.94)$ existed in never inundated areas followed by upland $(r=0.80)$. This finding can be explained by the fact that TCWI is closely associated with both soil moisture (Crist and Cicone 1984; Crist et al. 1986; Jian et al. 2012) and plant water content (Cohen 1991; Jin and Sader 2005; Toomey and Vierling 2005). TCWI takes the difference between a weighted sum of the visible/NIR reflectance and the SWIR reflectance (Table 3). TCWI would be most sensitive if the reflectance of both wavelength domains would change in the opposite direction. Figure 7 shows that this is not the case for any inundation class, but for the never inundated areas, the visible/NIR domain (469-858 nm) changes least while SWIR (1240-2130 nm) shows strong increases with decreasing water levels, resulting in a high sensitivity for TCWI. The likely explanation for this behavior in the never inundated class, is that TCWI responds here predominantly to changes in water content of soil and vegetation. These results are supported by the study of Ordoyne and Friedl (2008) who concluded that TCWI can quantify hydrological variation when the water table is below the soil surface. With an increase in the frequency of inundation, the TCWI-water level correlation decreased, indicating that TCWI might not appropriate for detecting variability in the presence of open water. It is rather an indicator of the water content of soil and vegetation. $\mathrm{LSWI}_{\mathrm{B} 6}$ exhibited a similar behavior to TCWI. The high LSWI $\mathrm{B}$-water level correlations for never inundated and upland areas confirm that $\mathrm{LSWI}_{\mathrm{B} 6}$ is also a good indicator of vegetation and soil water content (Chen et al. 2005; Xiao et al. 2005, 2006; Wang et al. 2008; Zhang et al. 2011).

NDWI had the highest correlation coefficient $(r=0.84)$ with water level for often inundated areas where the 
Fig. 6 Pearson's correlation coefficient between spectral indices derived from MODIS and measured water level for the 2000-2009 period for each MODIS pixel
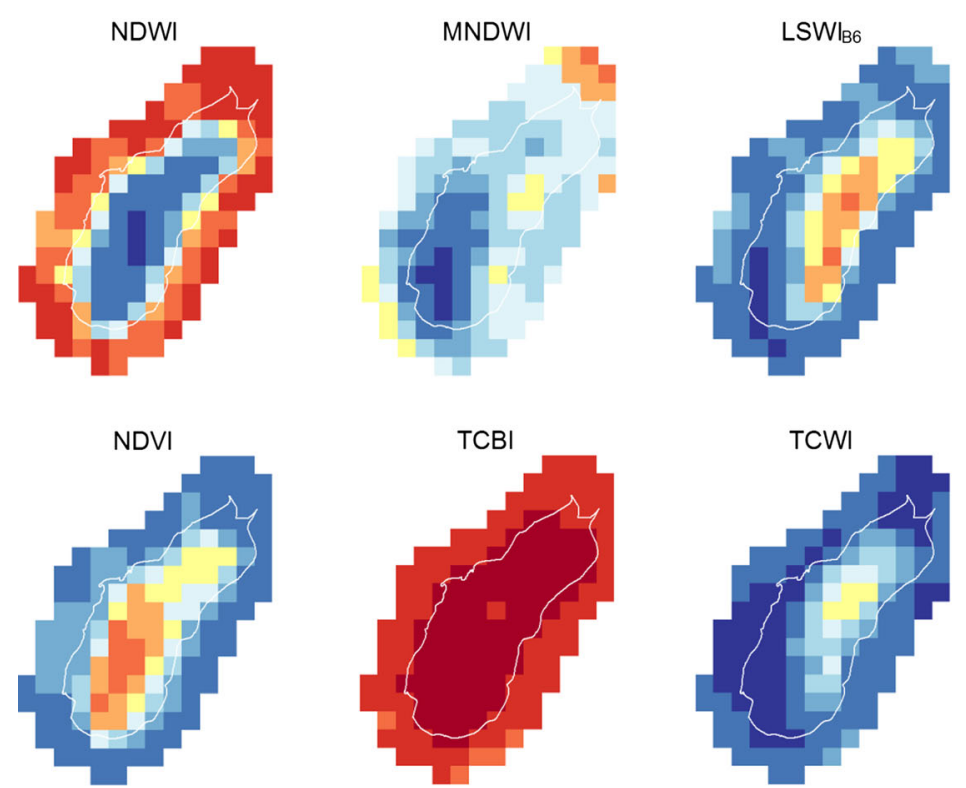
coefficient $(r)$

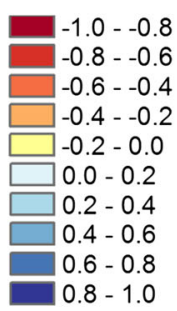

fluctuation in open-water presence is larger but low correlation coefficients in occasionally, seldom, and never inundated areas. This confirms that the index is able to monitor open water fluctuations, but not changes in soil water content. The upland class showed a high negative NDWI-water level correlation coefficient ( $r=-0.69)$, which can be explained by Fig. 7 that shows a decrease in green reflectance $(555 \mathrm{~nm})$ and a simultaneous increase in NIR reflectance $(858 \mathrm{~nm})$ for upland as water level increases above $0 \mathrm{~cm}$. This likely relates to reduced presence of green vegetation and/or the drying of vegetation around the lake at moments when the lake water level is low. Dry vegetation reflects less NIR radiation than green plants resulting in a higher NDWI.

NDVI showed high and positive correlations with water level for upland and never inundated areas but low and negative correlations inside the lake. For a wetland in Australia, Petus et al. (2013) also found differential NDVI temporal behavior inside the wetland as compared to the surrounding regions. This can be attributed to the fact that different wetland plant species have different phenological responses in relation to water availability (Baird and Wilby 1999; Van Trung et al. 2013). In large areas inside the lake, plants that are able to stand extreme drought and salinity may appear at low densities when water retreats. Instead, in the upland and never inundated areas of the lake, the vegetation is relatively dense and dominated by crops, marsh and scrub that strongly depend on water availability, which is higher with higher water tables. These opposite correlation signs for NDVI may also partially explain the low correction coefficient for NDVI and water level for the whole lake (Table 4). While a good index for monitoring green vegetation abundance in response to water level in vegetated wetlands such as marshes (Jiang et al. 2015), NDVI proved not be appropriate for monitoring wetland hydrology in this saline lake with sparse vegetation.

The dynamic range of TCBI, expressed by the $5^{\text {th }}$ to $95^{\text {th }}$ percentile range, varied greatly in relation to different inundation characteristics with a higher value of 0.72 for usually inundated areas and a low value of 0.38 for upland areas (Table 6). This difference in dynamic range suggests that the TCBI variability could be used to spatially separate seasonally-flooded wetlands from other areas, even if the temporal behavior is similar. Also MNDWI and NDWI showed higher variability for inundated areas as compared to uplands suggesting MNDWI and NDWI would also allow to separate wetlands clearly from its surroundings. An additional factor for NDWI to achieve this separation is the opposite temporal
Table 5 Pearson's correlation coefficients between spectral indices derived from MODIS for different inundation frequency zones and in-situ water level data over 2000-2009

\begin{tabular}{lclcccc}
\hline & NDWI & MNDWI & LSWI $_{\text {B6 }}$ & NDVI & TCBI & TCWI \\
\hline Upland & -0.69 & 0.40 & 0.81 & 0.79 & -0.73 & 0.80 \\
Never inundated & -0.11 & 0.85 & 0.86 & 0.61 & -0.86 & 0.94 \\
Seldom inundated & 0.21 & 0.47 & 0.46 & 0.42 & -0.89 & 0.75 \\
Occasionally inundated & 0.50 & 0.48 & 0.26 & 0.14 & -0.88 & 0.72 \\
Sometimes inundated & 0.70 & 0.51 & 0.09 & -0.26 & -0.86 & 0.53 \\
Often inundated & 0.84 & 0.57 & -0.08 & -0.45 & -0.84 & 0.33 \\
\hline
\end{tabular}




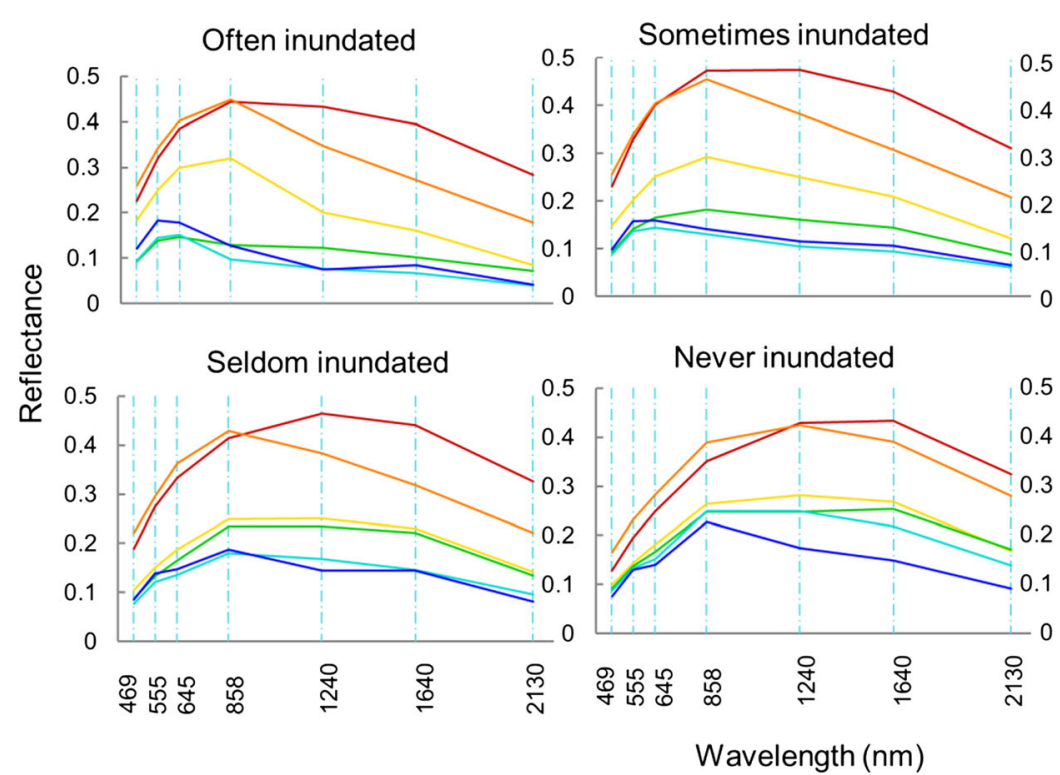

Water level $-31 \mathrm{~cm}$

$0 \mathrm{~cm}-21 \mathrm{~cm}$

Occasionally inundated

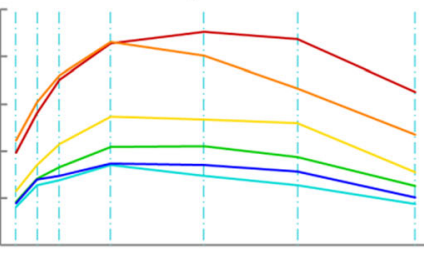

plands

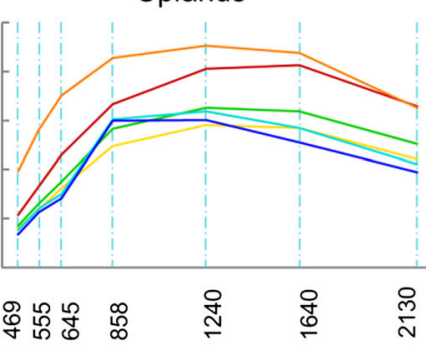

$-40 \mathrm{~cm}-63 \mathrm{~cm}$

Fig. 7 Average MODIS spectral signatures for the different inundation classes. The X-axis represents the central wavelength of each of the seven MODIS bands. Each line provides a spatial mean for an inundation class for a single image that corresponds to the water levels shown in the legend

behavior (Table 5 and Fig. 6). This implies that MODISderived indicates can, besides monitoring wetland hydrology, also play a role in identification and mapping of small wetlands, and monitoring of their extent.

\section{Future Outlook for Wetland Monitoring with Coarse Spatial Resolution Multi-Spectral Data}

Although our study was conducted for a single small wetland, it clearly showed the good potential of particularly the TCBI for wetland hydrological monitoring. We expect that this potential can be used for monitoring the hydrology of other wetlands with sparse vegetation cover in arid and semi-arid environments. The soils in and around the Fuente de Piedra lake are mostly mineral, which could have affected the results, because dry soils are bright (high TCBI) and wetter soils and inundated areas are dark (low TCBI) across the part of the electromagnetic spectrum considered here. Mineral soils, low in organic matter content, are the dominant soils in arid and semiarid environments. Soils with a higher organic matter content will also experience a decline in reflection when wetted or inundated, but given that such soils are already dark when in dry conditions, TCBI may possibly be less sensitive to this decline. Further studies in other wetlands should confirm the applicability and limitations of TCBI for monitoring wetland hydrology. Besides examining indices for wetlands with different soil types, we also recommend further testing for seasonally-flooded wetlands with other diverging characteristics, e.g. marshes with dense emergent vegetation, and for even smaller wetlands that comprise only a few MODIS pixels.

Closely monitoring hydrological variability is important for understanding how climate change and human actions affect the dynamics of seasonally-flooded wetlands, or may affect these in the future. Given that seasonally-flooded wetlands host a high diversity of fauna and flora that depend on these dynamics, we need tools to study them. This study demonstrated a promising option to monitor wetlands remotely using freelyavailable coarse spatial resolution but high temporal resolution data, which could benefit the hydrological monitoring of many seasonally-flooded wetlands globally. This in turn has potential to greatly contribute to the management and conservation of these habitats and species living in them.
Table 6 The 5th to 95th percentile variability as derived from the area-average time series of each spectral index per inundation class

\begin{tabular}{lllllll}
\hline & NDWI & MNDWI & LSWI $_{\text {B6 }}$ & NDVI & TCBI & TCWI \\
\hline Upland & 0.14 & 0.07 & 0.20 & 0.24 & 0.38 & 0.17 \\
Never inundated & 0.14 & 0.24 & 0.30 & 0.22 & 0.48 & 0.21 \\
Seldom inundated & 0.18 & 0.30 & 0.26 & 0.21 & 0.59 & 0.20 \\
Occasionally inundated & 0.18 & 0.36 & 0.25 & 0.15 & 0.64 & 0.20 \\
Sometimes inundated & 0.28 & 0.50 & 0.31 & 0.15 & 0.71 & 0.21 \\
Often inundated & 0.36 & 0.54 & 0.39 & 0.16 & 0.72 & 0.21 \\
\hline
\end{tabular}


Taking into account the importance of the Fuente de Piedra lake for conservation (e.g. for waterbirds), the results of this study may be directly applied for explaining animal species abundance by hydrological variability. Given that many of the waterbird species (e.g. the Greater Flamingo), are not confined to only this wetland, but make breeding and feeding decisions based on wetland conditions in a wider area, the MODIS indices may also be applied for assessing spatio-temporal variation of wetlands across Spain and the Mediterranean Basin (Amat et al. 2007). For example, the colony size of greater flamingos at Fuente de Piedra is also affected by water levels in the Guadalquivir marshes, which are located $140 \mathrm{~km}$ away. The Fuente de Piedra lake usually dries up during the late breeding season, and flamingos breeding in this locality must move to Guadalquivir marshes to obtain their food during the chick-rearing period (RendónMartos 1996). Hence, simultaneous monitoring hydrological dynamics of various wetlands with MODIS may prove an important tool to better explain and predict animal populations.

\section{Conclusion}

Seasonally-flooded wetlands are among the world's most unique and valuable ecosystems, but are under threat worldwide. Methods that allow monitoring these small wetlands from remote sensing are urgently needed by resource managers and ecologists, especially in areas where conflicts arise between the water demand for agriculture and conservation of wetlands in semi-arid environments. Results from this work suggest that the MODIS-derived spectral indices have good potential for characterizing and monitoring temporal variability in the hydrology of small seasonally-flooded wetlands. Particularly TCBI proved useful and gave consistent good results for wet and dry years, and for areas characterized by different inundation frequencies. This is relevant as it could provide opportunity to improve hydrological monitoring particularly for data-poor and ungauged wetlands. We recommend further testing of MODIS indices for hydrological monitoring of seasonally-flooded wetlands with different soil and vegetation characteristics. Besides wetland hydrological monitoring, the differential temporal behavior of MODIS indices within and outside the lake make these indices a promising tool for mapping and monitoring wetland extent over large areas.

Acknowledgments Funding for this work was provided by the China Scholarship Council (NO. 201206180040). Many thanks to the authorities of the Fuente de Piedra Natural Reserve and the Junta de Andalucía for providing the water level data used in this study, especially to Manuel Rendón. We thank Willem Nieuwenhuis for his help in programming and Dr Bert Toxopeus for his support.
Open Access This article is distributed under the terms of the Creative Commons Attribution 4.0 International License (http:// creativecommons.org/licenses/by/4.0/), which permits unrestricted use, distribution, and reproduction in any medium, provided you give appropriate credit to the original author(s) and the source, provide a link to the Creative Commons license, and indicate if changes were made.

\section{References}

Alsdorf D, Lettenmaier D, Vörösmarty C (2003) The need for global, satellite-based observations of terrestrial surface waters. Eos, Transactions American Geophysical Union 84:269-276

Alsdorf DE, Rodriguez E, Lettenmaier DP (2007) Measuring surface water from space. Reviews of Geophysics 45:1-24

Amat JA, Hortas F, Arroyo GM et al (2007) Interannual variations in feeding frequencies and food quality of greater flamingo chicks (Phoenicopterus roseus): evidence from plasma chemistry and effects on body condition. Comparative Biochemistry and Physiology Part A: Molecular \& Integrative Physiology 147:569-576

Bai J, Chen X, Li J et al (2011) Changes in the area of inland lakes in arid regions of central Asia during the past 30 years. Environmental Monitoring and Assessment 178:247-256

Baird AJ, Wilby RL (1999) Eco-hydrology: plants and water in terrestrial and aquatic environments. Psychology Press

Baldwin RF, Calhoun AJK, deMaynadier PG (2006) The significance of hydroperiod and stand maturity for pool-breeding amphibians in forested landscapes. Canadian Journal of Zoology - Revue Canadienne De Zoologie 84:1604-1615

Beck PSA, Atzberger C, Hogda KA et al (2006) Improved monitoring of vegetation dynamics at very high latitudes: a new method using MODIS NDVI. Remote Sensing of Environment 100:321-334

Borro M, Morandeira N, Salvia M et al (2014) Mapping shallow lakes in a large South American floodplain: a frequency approach on multitemporal Landsat TM/ETM data. Journal of Hydrology 512: $39-52$

Bourgeau-Chavez LL, Smith KB, Brunzell SM et al (2005) Remote monitoring of regional inundation patterns and hydroperiod in the greater everglades using synthetic aperture radar. Wetlands 25:176-191

Campbell JB (2002) Introduction to remote sensing. CRC Press, London

Campos JC, Sillero N, Brito JC (2012) Normalized difference water indexes have dissimilar performances in detecting seasonal and permanent water in the Sahara-Sahel transition zone. Journal of Hydrology 464-465:438-446

Castañeda C, Herrero J (2008) Assessing the degradation of saline wetlands in an arid agricultural region in Spain. Catena 72:205-213

Chen D, Huang J, Jackson TJ (2005) Vegetation water content estimation for corn and soybeans using spectral indices derived from MODIS near- and short-wave infrared bands. Remote Sensing of Environment 98:225-236

Chen Y, Huang C, Ticehurst C et al (2013) An evaluation of MODIS daily and 8-day composite products for floodplain and wetland inundation mapping. Wetlands 33:823-835

Chipman JW, Lillesand TM (2007) Satellite-based assessment of the dynamics of new lakes in southern Egypt. International Journal of Remote Sensing 28:4365-4379

Cohen WB (1991) Response of vegetation indexes to changes in 3 measures of leaf water-stress. Photogrammetric Engineering and Remote Sensing 57:195-202

Conde-Álvarez RM, Bañares-España E, Nieto-Caldera JM et al (2012) Submerged macrophyte biomass distribution in the shallow saline lake Fuente de Piedra (Spain) as function of environmental variables. Anales del Jardin Botánico de Madrid 69:119-127 
Crist EP (1985) A TM Tasseled Cap equivalent transformation for reflectance factor data. Remote Sensing of Environment 17:301-306

Crist EP, Cicone RC (1984) A physically-based transformation of thematic mapper data - the TM Tasseled Cap. IEEE Transactions on Geoscience and Remote Sensing 22:256-263

Crist EP, Laurin R, Cicone RC (1986) Vegetation and soils information contained in transformed Thematic Mapper data. In: Proceedings of IGARSS'86 Symposium. pp 1465-1470. European Space Agency Paris. http://www.ciesin.org/docs/005-419/005-419.html

Davranche A, Poulin B, Lefebvre G (2013) Mapping flooding regimes in Camargue wetlands using seasonal multispectral data. Remote Sensing of Environment 138:165-171

Eitel JUH, Gessler PE, Smith AMS et al (2006) Suitability of existing and novel spectral indices to remotely detect water stress in Populus spp. Forest Ecology and Management 229:170-182

Feng L, Hu CM, Chen XL et al (2012) Assessment of inundation changes of Poyang Lake using MODIS observations between 2000 and 2010. Remote Sensing of Environment 121:80-92

Gao BC (1996) NDWI - a normalized difference water index for remote sensing of vegetation liquid water from space. Remote Sensing of Environment 58:257-266

García CM, Niell FX (1993) Seasonal change in a saline temporary lake (Fuente de Piedra, southern Spain). Hydrobiologia 267:211-223

García CM, García-Ruiz R, Rendón M et al (1997) Hydrological cycle and interannual variability of the aquatic community in a temporary saline lake (Fuente de Piedra, southern Spain). Hydrobiologia 345:131-141

Geraci J, Bechet A, Cezilly F et al (2012) Greater flamingo colonies around the Mediterranean form a single interbreeding population and share a common history. Journal of Avian Biology 43:341-354

Gibbs JP (1993) Importance of small wetlands for the persistence of localpopulations of wetland-associated animals. Wetlands 13:25-31

Guerschman JP, Warren G, Byrne G et al (2011) MODIS-based standing water detection for flood and large reservoir mapping: algorithm development and applications for the Australian continent. CSIRO: Water for a Healthy Country National Research Flagship Report, Canberra, Australia

Haas EM, Bartholomé E, Combal B (2009) Time series analysis of optical remote sensing data for the mapping of temporary surface water bodies in sub-Saharan western Africa. Journal of Hydrology 370:52-63

Habitats Directive (1992) Council Directive 92/43/EEC of 21 May 1992 on the conservation of natural habitats and of wild fauna and flora. The Council of the European Communities. http://eur-548lex. europa.eu/legal-content/EN/TXT/?uri=CELEX:31992L0043

Hayashi M, van der Kamp G (2000) Simple equations to represent the volume-area-depth relations of shallow wetlands in small topographic depressions. Journal of Hydrology 237:74-85

Heredia J, García de Domingo A, Ruiz JM et al (2010) Fuente de Piedra Lagoon (Málaga, Spain): a deep Karstic flow discharge point of a regional hydrogeological system. In: Andreo B, Carrasco F, Durán JJ, LaMoreaux JW (eds) Advances in research in Karst media. Springer, Berlin, pp 231-236

Herrero J, Castaneda C (2009) Delineation and functional status monitoring in small saline wetlands of NE Spain. Journal of Environmental Management 90:2212-2218

Howari F, Goodell P, Miyamoto S (2002) Spectral properties of salt crusts formed on saline soils. Journal of Environmental Quality 31:14531461

Huang C, Chen Y, Wu J (2014) Mapping spatio-temporal flood inundation dynamics at large river basin scale using time-series flow data and MODIS imagery. International Journal of Applied Earth Observation and Geoinformation 26:350-362

Irish R (2000) Landsat 7 science data users handbook. National Aeronautics and Space Administration, Report: 430-415. http:// landsathandbook.gsfc.nasa.gov/

Jensen JR (2009) Remote sensing of the environment: an earth resource perspective 2/e. Pearson Education India, New Delhi
Ji L, Zhang L, Wylie B (2009) Analysis of dynamic thresholds for the Normalized Difference Water Index. Photogrammetric Engineering and Remote Sensing 75:1307-1317

Ji L, Zhang L, Wylie BK et al (2011) On the terminology of the spectral vegetation index (NIR - SWIR)/(NIR + SWIR). International Journal of Remote Sensing 32:6901-6909

Jian J, Yang WN, Jiang H et al (2012) A model for retrieving soil moisture saturation with Landsat remotely sensed data. International Journal of Remote Sensing 33:4553-4566

Jiang H, Liu C, Sun X et al (2015) Remote sensing reversion of water depths and water management for the stopover site of siberian cranes at Momoge, China. Wetlands 35:369-379

Jin S, Sader SA (2005) Comparison of time series tasseled cap wetness and the normalized difference moisture index in detecting forest disturbances. Remote Sensing of Environment 94:364-372

Jung HC, Alsdorf D, Moritz M et al (2011) Analysis of the relationship between flooding area and water height in the Logone floodplain. Physics and Chemistry of the Earth, Parts A/B/C 36:232-240

Kauth RJ, Thomas GS (1976) The tasselled cap - a graphic description of the spectral-temporal development of agricultural crops as seen by Landsat. Proceedings of the Symposium on Machine Processing of Remotely Sensed Data: 4B-41-44B-50

Kim J-W, Lu Z, Jones JW et al (2014) Monitoring Everglades freshwater marsh water level using L-band synthetic aperture radar backscatter. Remote Sensing of Environment 150:66-81

Kohfahl C, Rodriguez M, Fenk C et al (2008) Characterising flow regime and interrelation between surface-water and ground-water in the Fuente de Piedra salt lake basin by means of stable isotopes, hydrogeochemical and hydraulic data. Journal of Hydrology $351: 170-187$

Koning CO (2005) Vegetation patterns resulting from spatial and temporal variability in hydrology, soils, and trampling in an isolated basin marsh, New Hampshire, USA. Wetlands 25:239-251

Koshal AK (2012) Spectral characteristics of soil salinity areas in parts of South-West Punjab through Remote Sensing and GIS. International Journal of Remote Sensing and GIS 1:84-89

Leibowitz SG (2003) Isolated wetlands and their functions: an ecological perspective. Wetlands 23:517-531

Li RR, Kaufman YJ, Gao BC et al (2003) Remote sensing of suspended sediments and shallow coastal waters. IEEE Transactions on Geoscience and Remote Sensing 41:559-566

Liu X, Zhang S, Li X (1983) The application of Landsat image in the surveying of water resources of Dongting Lake. Proceedings of the Hamburg Symposium 145:483-489

Mahe G, Orange D, Mariko A et al (2011) Estimation of the flooded area of the Inner Delta of the River Niger in Mali by hydrological balance and satellite data. In: Franks SW, Boegh E, Blyth E, Hannah DM, Yilmaz KK (eds) Hydro-climatology: variability and change. Int Assoc Hydrological Sciences, Wallingford, pp 138-143

Mahe G, Mariko A, Orange D (2013) Relationships between water level at hydrological stations and inundated area in the River Niger Inner Delta, Mali. In: Young G, Perillo GM (eds) Deltas: landforms, ecosystems and human activities. Int Assoc Hydrological Sciences, Wallingford, pp 110-115

Marti-Cardona B, Lopez-Martinez C, Dolz-Ripolles J et al (2010) ASAR polarimetric, multi-incidence angle and multitemporal characterization of Doñana wetlands for flood extent monitoring. Remote Sensing of Environment 114:2802-2815

McFeeters SK (1996) The use of the normalized difference water index (NDWI) in the delineation of open water features. International Journal of Remote Sensing 17:1425-1432

Medina C, Gomez-Enri J, Alonso JJ et al (2010) Water volume variations in Lake Izabal (Guatemala) from in situ measurements and ENVISAT Radar Altimeter (RA-2) and Advanced Synthetic Aperture Radar (ASAR) data products. Journal of Hydrology 382: $34-48$ 
Ministry of Agriculture, Fisheries and Environment (2013) Por el que se declara la Zona especial de conservación Laguna de Fuente de Piedra (eS0000033) y se aprueba el Plan de ordenación de los recursos Naturales de la reserva Natural Laguna de Fuente de Piedra. Boletín Oficial de la Junta de Andalucía

O'Grady D, Leblanc M (2014) Radar mapping of broad-scale inundation: challenges and opportunities in Australia. Stochastic Environmental Research and Risk Assessment 28:29-38

Olsen JL, Ceccato P, Proud SR et al (2013) Relation between seasonally detrended shortwave infrared reflectance data and land surface moisture in semi-arid Sahel. Remote Sensing 5:2898-2927

Ordoyne C, Friedl MA (2008) Using MODIS data to characterize seasonal inundation patterns in the Florida Everglades. Remote Sensing of Environment 112:4107-4119

Otsu N (1979) Threshold selection method from gray-level histograms. IEEE Transactions on Systems, Man, and Cybernetics 9:62-66

Pettorelli N, Vik JO, Mysterud A et al (2005) Using the satellite-derived NDVI to assess ecological responses to environmental change. Trends in Ecology \& Evolution 20:503-510

Petus C, Lewis M, White D (2013) Monitoring temporal dynamics of Great Artesian Basin wetland vegetation, Australia, using MODIS NDVI. Ecological Indicators 34:41-52

Ramsar Convention on Wetlands (2002) Wetlands: water, life and culture. In: Resolution VIII.33 Guidance for identifying, sustainably managing, and designating temporary pools as Wetlands of International. http://www.ramsar.org/sites/default/files/documents/pdf/res/key_ res_viii_33_e.pdf

Rendón-Martos M (1996) La laguna de Fuente de Piedra en la dinámica de la población de flamencos "(Phoenicopterus ruber roseus)" del Mediterráneo occidental. Dissertation, University of Málaga

Richards JA, Woodgate PW, Skidmore AK (1987) An explanation of enhanced radar backscattering from flooded forests. International Journal of Remote Sensing 8:1093-1100

Robledano F, Esteve MA, Farinos P et al (2010) Terrestrial birds as indicators of agricultural-induced changes and associated loss in conservation value of Mediterranean wetlands. Ecological Indicators 10:274-286

Rodriguez YC, El Anjoumi A, Gomez JAD et al (2014) Using Landsat image time series to study a small water body in Northern Spain. Environmental Monitoring and Assessment 186:3511-3522

Rokni K, Ahmad A, Selamat A et al (2014) Water feature extraction and change detection using multitemporal landsat imagery. Remote Sensing 6:4173-4189

Roshier DA, Whetton PH, Allan RJ et al (2001) Distribution and persistence of temporary wetland habitats in arid Australia in relation to climate. Austral Ecology 26:371-384

Roshier DA, Robertson AI, Kingsford RT (2002) Responses of waterbirds to flooding in an arid region of Australia and implications for conservation. Biological Conservation 106:399-411

Ruiz E (2008) Management of Natura 2000 habitats. 3170* Mediterranean temporary ponds. European Commission 1-19

Schaaf CB, Gao F, Strahler AH et al (2002) First operational BRDF, albedo nadir reflectance products from MODIS. Remote Sensing of Environment 83:135-148

Semlitsch RD, Bodie JR (1998) Are small, isolated wetlands expendable? Conservation Biology 12:1129-1133

Sim LL, Davis JA, Strehlow K et al (2013) The influence of changing hydroregime on the invertebrate communities of temporary seasonal wetlands. Freshwater Science 32:327-342

Sippel SJ, Hamilton SK, Melack JM et al (1998) Passive microwave observations of inundation area and the area/stage relation in the Amazon River floodplain. International Journal of Remote Sensing 19:3055-3074

Smith LC (1997) Satellite remote sensing of river inundation area, stage, and discharge: a review. Hydrological Processes 11:1427-1439
Toomey M, Vierling LA (2005) Multispectral remote sensing of landscape level foliar moisture: techniques and applications for forest ecosystem monitoring. Canadian Journal of Forest Research 35: 1087-1097

Tornos L, Huesca M, Dominguez JA et al (2015) Assessment of MODIS spectral indices for determining rice paddy agricultural practices and hydroperiod. ISPRS Journal of Photogrammetry and Remote Sensing 101:110-124

Townsend PA (2001) Mapping seasonal flooding in forested wetlands using multi-temporal radarsat SAR. Photogrammetric Engineering and Remote Sensing 67:857-864

Tucker CJ (1979) Red and photographic infrared linear combinations for monitoring vegetation. Remote Sensing of Environment 8:127-150

Van Trung N, Choi JH, Won JS (2013) A land cover variation model of water level for the floodplain of Tonle Sap, Cambodia, derived from ALOS PALSAR and MODIS data. IEEE Journal of Selected Topics in Applied Earth Observations and Remote Sensing 6:2238-2253

Vrieling A, de Beurs KM, Brown ME (2011) Variability of African farming systems from phenological analysis of NDVI time series. Climatic Change 109:455-477

Vrieling A, de Leeuw J, Said MY (2013) Length of growing period over Africa: variability and trends from 30 years of NDVI time series. Remote Sensing 5:982-1000

Wang C (2008) Detecting the effect of water regime on waterbirds population using remote sensing. Dissertation, University of Twente

Wang LL, Qu JJ, Hao XJ et al (2008) Sensitivity studies of the moisture effects on MODIS SWIR reflectance and vegetation water indices. International Journal of Remote Sensing 29:7065-7075

Waterkeyn A, Grillas P, Vanschoenwinkel B et al (2008) Invertebrate community patterns in Mediterranean temporary wetlands along hydroperiod and salinity gradients. Freshwater Biology 53:18081822

Wdowinski S, Kim SW, Amelung F et al (2008) Space-based detection of wetlands' surface water level changes from L-band SAR interferometry. Remote Sensing of Environment 112:681-696

Xiao X, Boles S, Frolking S et al (2002a) Observation of flooding and rice transplanting of paddy rice fields at the site to landscape scales in China using VEGETATION sensor data. International Journal of Remote Sensing 23:3009-3022

Xiao XM, Boles S, Liu JY et al (2002b) Characterization of forest types in Northeastern China, using multi-temporal SPOT-4 VEGETATION sensor data. Remote Sensing of Environment 82:335-348

Xiao XM, Boles S, Liu JY et al (2005) Mapping paddy rice agriculture in southern China using multi-temporal MODIS images. Remote Sensing of Environment 95:480-492

Xiao XM, Boles S, Frolking S et al (2006) Mapping paddy rice agriculture in South and Southeast Asia using multi-temporal MODIS images. Remote Sensing of Environment 100:95-113

$\mathrm{Xu}$ HQ (2006) Modification of normalised difference water index (NDWI) to enhance open water features in remotely sensed imagery. International Journal of Remote Sensing 27:3025-3033

Yan YE, Ouyang ZT, Guo HQ et al (2010) Detecting the spatiotemporal changes of tidal flood in the estuarine wetland by using MODIS time series data. Journal of Hydrology 384:156-163

Zacharias I, Zamparas M (2010) Mediterranean temporary ponds. A disappearing ecosystem. Biodiversity and Conservation 19:38273834

Zacharias I, Dimitriou E, Dekker A et al (2007) Overview of temporary ponds in the Mediterranean region: threats, management and conservation issues. Journal of Environmental Biology 28:1-9

Zhang XY, Schaaf CB, Friedl MA et al (2002) MODIS tasseled cap transformation and its utility. Geoscience and Remote Sensing Symposium. doi:10.1109/IGARSS.2002.1025776

Zhang L, Ji L, Wylie BK (2011) Response of spectral vegetation indices to soil moisture in grasslands and shrublands. International Journal of Remote Sensing 32:5267-5286 